\title{
Saudi Airlines Service Quality: Passengers' Perceptions toward SAUDIA Operational Procedures Pre-flight Services: An Empirical Investigation
}

\author{
Hani A. AlGhamdi \\ ${ }^{1}$ Faculty of Economics and Administration, King Abdulaziz University, Jeddah, Saudi Arabia \\ Correspondence: Hani A. AlGhamdi, Faculty of Economics and Administration, King Abdulaziz University, \\ Jeddah, Saudi Arabia. E-mail: halghamdi0251@stu.kau.edu.sa
}

Received: October 16, 2019

Accepted: November 6, 2019

Online Published: December 14, 2019

doi:10.5539/ijbm.v15n1p122

URL: https://doi.org/10.5539/ijbm.v15n1p122

\begin{abstract}
The study aimed at assessing service quality (SQ) of Saudi Arabian Airlines (SAUDIA); the sole national air transporter in Saudi Arabia. Considering the SERVQUAL model developed by Parasuraman et al. (1985), the study used a developed scale dedicated to Airlines industry. The nine dimensions scale "ASQUAL" included: declaration practices, planning practices, front offices procedures, technological self-processes, crew practices, operational procedures, equipping processes, hospitality practices, and warranty procedures. Among those dimensions, this study focused on the ASQUAL sixth dimension: operational procedures. For this purpose, 502 questionnaires were collected and analyzed from different gender, passengers classes, educational levels, and ages. With its Eight factors, the operational procedures dimension used in this study and revealed that the passengers were in general unsatisfied about the quality of the operational procedures services (OPSQ) provided by SAUDIA. The measured factors were: Waiting Time (Counters Queue), Frequent Announcements (Final Boarding \& Pre-flight), On-Time (Flight Departure), Waiting Time (Baggage Arrival). The other remaining factors were: Announcement (Guidance to Specific Baggage Carousel), Safety (Delivered Baggage), Announcement (Replacement for Delayed Flight), and Pre-announcement (Replacement for Canceled Flight / 7+ Days Prior). The study showed that there -at least- two operational services were unoffered by SAUDIA. The contributions of this study to the existent literature in services quality are assessed together with the contributions made to the air transport industry. The limitations of the study discussed, the recommendations addressed, and the potential for future research in this filed indicated.
\end{abstract}

Keywords: ASQUAL, customers, passengers, perception, quality, Saudia, Saudi Arabia, services

\section{Introduction}

\subsection{Background}

On May 27, 1945, the first flight of the air traffic was launched in the Kingdom of Saudi Arabia a single twin-engine DC-3 (Dakota) given to King Abdul Aziz as a gift by the U.S. President Franklin D. Roosevelt, which began to operate passengers between Riyadh, Jeddah, and Dhahran.

In September 1946, the establishment of SAUDIA announced and adopted (SDI) as its slogan. SDI was affiliating to the Ministry of Defense and Aviation. In 1948, five DC-4 and five other Bristol 170 aircraft were purchased to support the international flight network. SAUDIA today has 143 aircraft from the latest Boeing B787-9 Dreamliner, B777-268, B777-300ER, Airbus A320-200, A321 and A330-300 aircraft.

In 1988, SAUDIA was providing a range of ground handling services for local carriers, and foreign carriers, Hajj and Umrah flights, and Royal and VIP flights by Saudi Arabian Airline Ground Services. SAAGS handle over 150,000 flights annually in 26 international, regional, and domestic airports.

In line with the strategic objective espoused by the Saudi Government to open the aviation sector, Saudi Ground Services established in 2011. Saudi Arabian Airline Ground Services (SAAGS) was one of the three ground service providers were operative within Saudi Arabia, that amalgamated under the Saudi Ground Services (SGS).

\subsection{Importance}

The importance of this study came from the scarcity of studies on the SQ of the aviation sector in Saudi Arabia, 
as this sector represented in a country the size of Saudi Arabia. Which contributes to highlighting the quality of services in this sector and encourages researchers to undertake a further study that addresses other aspects complementary to this study. The results of such studies will contribute to making more recommendations to service providers in the aviation sector.

\subsection{Instrument}

Many studies embarked on identifying a framework for service quality. As a measurement tool, SERVQUAL is the most prominent scale that applied in both business and academic fields which developed by (Parasuraman, A. et al., 1985) and was his ten dimensions scale trend to measure the SQ arena in a general manner. Therefore, the use of the ASQUAL scale, which developed to be a dedicated scale to measure the SQ for the Airlines field, was a significant procedure.

\subsection{Aims}

Following a brief review of the most significant changes in Saudi Arabian Airlines (SAUDIA), this study came to assess the quality services provided by this company from the perspective of its passengers using a scale commensurate with the industry.

This study aims to investigate SQ in Airline industry by exploring the passengers' perceptions toward the operational procedures SQ (OPSQ) provided by SAUDIA. The study also seeks to develop an understanding of whether the perceived OPSQ is having a significant influence on travelers' satisfaction, where it is the ultimate goal for every single air carrier worldwide.

\subsection{Limitations}

The scope of this study is limited to some demographical group, where those who only flew within SAUDIA will be addressing in the study's survey. This study will cover and assess the quality of the OPSQ provided by SAUDIA only, and will not be covering other dimensions or factors, nor the prices or any other unmentioned aspects. Future studies may find a potential by making determined efforts to deal with such relevant topics.

\section{Literature Review}

Unlike other industries, Airline industry possesses unique circumstances and state of affairs. Amidst the revolution of quality concept, where manufacturers and industrialists disseminate the evolution of quality principles to confront fierce competitions and reduce the productions costs, quality concept turned into a significant pattern and became an infection that hit all the facilities and production processes and phases.

The great solicitude by all industrial sectors toward the quality concept has facilitated it to crept then penetrated services sectors and sprawled to varying categories in service areas.

In contrast, among all service industries, Airline is the stumbling block in a paved way for a new era embraces such an influential weighty concept on industrial and businesses revolution that is called "Quality."

Quality is a widespread term in today's literature. Obviously, that quality importance to service sectors is incontrovertible and unambiguously. Coupled with that, the quality notion in air transportation is not a luxuriant concept.

\subsection{Airline Industry Background}

Not to mention that Air transport remains an enormous and thriving industry. Such industry is a pillar of supporting economic growth, coupled with a tremendous contribution to trade, investment tourism worldwide and is, therefore, among many other industries, popped up as the primary factor to emergence the era of "global village". (IATA, 2015) Has published a recent statistical report to illuminate the importance of Airline industry in today's world.

In contrast, quality of air transport is indispensable for an industry that embraces 1397 commercial airlines, landed on about 3864 commercial airports. Moreover, 173 air navigation service providers monitor 25332 aircraft in service, to serve 3.3 billion passengers within 49871 routes, and 36.4 million flights (IATA, 2015). 


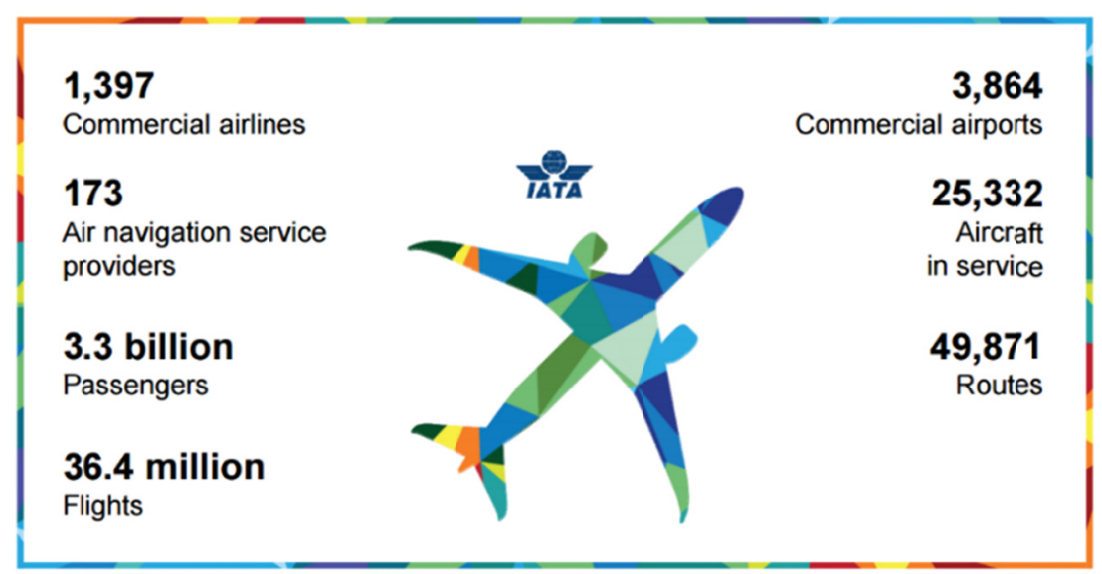

Figure 1. (A) Economic and Social Benefits of Air Transport (Source: IATA, 2015)

Equally important, in this industry, more than 58.1 million Jobs supported while at least a $35 \%$ of world trade by value ( $\$ 6.4$ trillion). Coupled with $\$ 2.4$ trillion GDP that supported (3.4\%), and $52 \%$ of tourists fly to their destinations, amidst a social cohesion impact on more people have access to air travel than ever, ultimately led to connectivity for today's modern world.

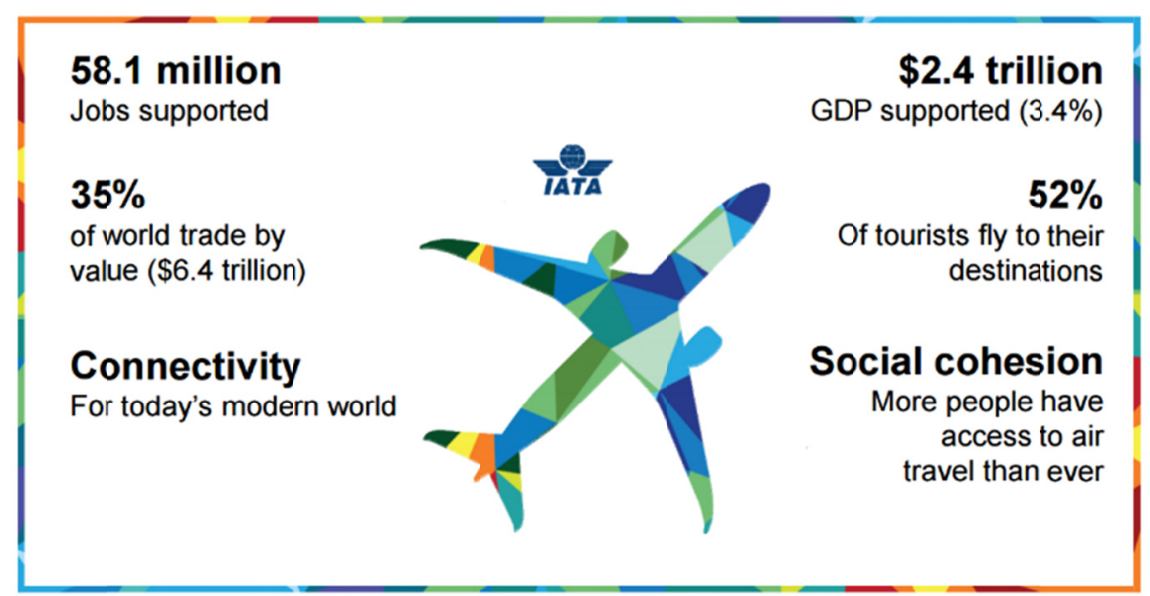

Figure 2. (B) Economic and Social Benefits of Air Transport (Source: IATA, 2015)

Correspondingly, equally important, it is Airline industry onus to provide and develop services are of consistent, high quality. Such demeanor leads to embracing customers' confidence in all types of services and helps to confront business competition climate, bringing concrete economic benefits. Moreover, it would result in reducing customer complaints and pave the way to ensure the quality of service delivery is repositioning and rising to match services' importance among economies around the world.

Academics have enriched SQ topics including Airline industry. Economics, marketing, and operations management issues have investigated throughout generations of interest to explore minor details affect sensitive business pallor, like profit maximization, buying behavior and customer satisfaction, engineering practices and manufacturing control. Away from academics' terminology, practitioners focus on practical aspects, more precisely, on actual circumstances and ultimate result. 


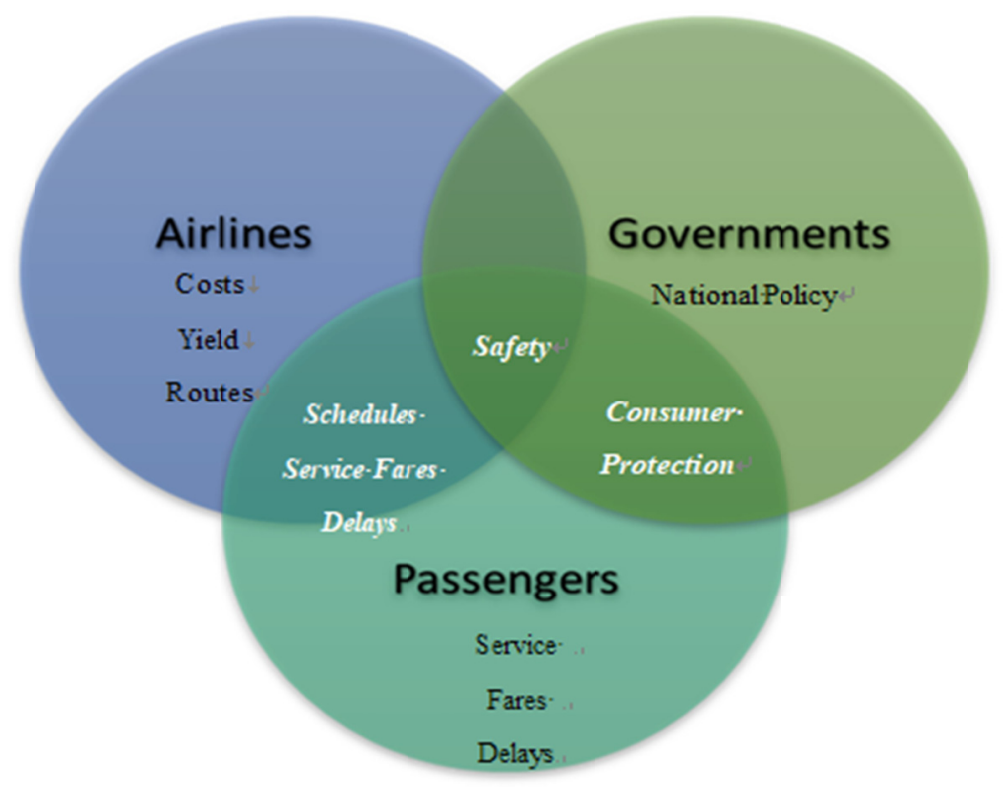

Figure 3. Mutually supportive spheres of interest in commercial transportation

\subsection{Economic and Social Benefits of Air Transport}

Economic and social aspects are the ultimate goal for business and academics activities. Improving those two factors would cause a significant change in the people daily life and became a significant stimulus for continuous developments. (IATA, 2015) In recent report has cast further light on the impact of air transport in this context. The report reviewed aspects like the implications of air transportation, the direct and indirect impact on employment file, also illustrated few statistics and the efficiency of this industry.

Air transportation services differ from another service is being produced and presented not only by airlines but "it is really a joint effort involving the airlines and the government" according to (Gourdin, 1988). By the same token, passengers are not services beneficiaries only, but they are a significant influence factor that affects the provided service.

Coupled with their role - as services beneficiaries - the passengers could play more complex roles in the backyard of service production by being a reason to delay a flight carrying hundreds of passengers for hours or days. Not to mention the huge probability of impact on security procedures, which consequently led to touch the prestige of "quality" term. (Figure 3) Depicts the ideal situation where the needs of each group are mutually satisfied according to (Gourdin, 1988). Airlines are in charge of cost, yield, and routes. The government in charge of national policy only, while passengers in charge of service, fares, and delays.

In the light of shared roles, Airlines and passengers are both in charge of schedules, service, fares, and delays. Government and passengers are both in charge of consumer protection. Not to say nothing of the equally important role of all parties towards the safety, government and airlines have not a shared role towards the quality. As can be seen at (Figure 3) shows each of the three parties has particular independent roles, whereas overlapping areas show the interconnected relationships that reflect shared roles and responsibilities.

Notwithstanding (Wu, H. C., \& Cheng, C. C., 2013) believes that there was not an identified scale for SQ in Airline industry to measure the actual passengers' perceptions amongst entire literature. Literature shows that there were many researchers attempted to determine main dimensions of the SQ in the Airline industry. (Khatib, 1998) conducted an academic study investigating the ASQ (Airline Service Quality), and overviewed the main studies contributed to enrich such field.

\section{Research Design}

This research project utilizes description, where it tends to be a precursor to explanation. Consequently, this research classified as so-called in research methods as descripto-explanatory studies (Saunders, M and Lewis, $\mathrm{P}$ and Thornhill, A, 2009). This research is on theoretical and empirical methodology basis. The secondary data obtained through the review of the literature including textbooks and journals. Also, primary data collected within 21 days in early October 2015, where the research questionnaire was an essential data resource for the 
purpose of data collection.

\subsection{Approaches and Designs}

The quantitative approach adopted in this research. The "quantitative" term coincides predominantly with any data collection techniques and relies on instruments (such as questionnaires) and data analysis procedures (such as graphs or statistics) that generate or uses numerical data (Saunders, M and Lewis, P and Thornhill, A, 2009). According to (Grove et al., 2014) the quantitative research defined as a formal, objective, systematic process in which numerical data are used to obtain information about the world.

However, a descriptive method conducted. According to (Grove, S. K., Gray, J. R., \& Burns, N., 2014) conducting quantitative research is foremost to test theories by describing variables (such as descriptive studies) and or examining relationships among variables, which has been carried out in this research.

\subsection{Target Population}

(McLeod, 2014) Define the target population as the total group of individuals from which the sample might be drawn. The research scope of this thesis targeted to the passengers of air transportation flying with Saudi Airlines, including the Saudi travelers who were living abroad during the questionnaire disruption period, for different purposes.

\subsection{Sampling}

In this research, the adopted sampling method was probability (representative) sampling, where it is the most commonly associated with survey-based research strategies. A sample is the group of people who take part in the investigation. The people who take part referred to as "participants" (McLeod, 2014). According to (Saunders, M and Lewis, P and Thornhill, A, 2009) for most business and management research, researchers are the content to estimate the population's characteristics with 95 percent certainty to within plus or minus 3 to 5 percent of its true values.

In this research, the adopted sample size of the population is at a 95-confidence level, where researchers normally work to a 95 percent level of certainty. Consequently, the minimum required sample cases in such confidence level are 384 participants; while this research conducted with at least 502 participants representing the sample of the targeted population.

\subsection{Types of Questionnaire's Questions}

To have the passengers' perceptions toward SAUDIA OPSQ assessed, a 5-point Likert scale was employed to obtain a nominal categorical data. Consequently, the respondents were asked to rate their level of satisfaction about each stated statement on a scale starting from 1-5 (Strongly Unsatisfied, Unsatisfied, Neutral, Satisfied, Strongly Satisfied). The five-point scale can be transformed to a Mean Item Score (MIS) for each of statements, where it can be ranked in descending order (from the highest to the lowest) while weight can be assigned to each response.

\section{Section A: Respondents Demographic \& Travel Profile}

Representing the First part, section A consisted of gender, age, and educational level questions, classified as categorical questions, while Travel Class question was multiple choice question.

\section{Section B: SAUDIA Pre-Flight OPSQ}

Representing the Second part, section B consisted of 8 questions discussed the respondent's perceptions toward SAUDIA Pre-Flight OPSQ, contained six questions classified as (level of satisfaction - five-point Likert scale). While the remaining two questions were a close-ended (Yes/No) questions, where both coded as (NO:1), (Yes:2). (Table 1) illustrate the (level of satisfaction - five-point Likert scale), scale coding, mean, median, and mode.

Table 1. (Level of satisfaction) five-point Likert scale

\begin{tabular}{lllll}
\hline Code & Statement & Mean & Median & Mode \\
\hline 1 & Strongly Unsatisfied & 1.00 to 1.79 & 1 & 2 \\
2 & Unsatisfied & 1.80 to 2.59 & 3 & 3 \\
3 & Neutral & 2.60 to 3.39 & 4 & 4 \\
4 & Satisfied & 3.40 to 4.19 & 5 & 5 \\
\hline
\end{tabular}




\section{Research Findings}

\subsection{Respondents Demographic \& Travel Profile (Table 2)}

The sample distribution according to Gender reflects that out of 502 respondents $77 \%$ were Male while $23 \%$ were Female. In other words, three-quarters of the respondents were Male.

The Age sample distribution reveals that $45 \%$ were at a range of 26-35 Years, 25\% were 36-45 Years while 16-25 were about $18 \%$. In other words, the range from $26-45$ represents about $70 \%$ of the 502 respondents. The Education sample distribution reveals that $57 \%$ represented bachelor's degree while Master degree represented by $24 \%$. In other words, about $81 \%$ of respondents possess a higher level of education.

The sample distribution according to Preferred Booking Option) reveals that $67 \%$ were economy class travelers, while there were about $25 \%$ traveling in business class, and $8 \%$ were first class seat travelers.

Table 2. Sample distribution according to gender

\begin{tabular}{|c|c|c|}
\hline Gender & Frequency & Percent \\
\hline Male & 387 & $77.09 \%$ \\
\hline Female & 115 & $22.91 \%$ \\
\hline Total & 502 & $100.00 \%$ \\
\hline Age & Frequency & Percent \\
\hline $16-25$ Years & 88 & $17.53 \%$ \\
\hline $26-35$ Years & 226 & $45.02 \%$ \\
\hline $36-45$ Years & 127 & $25.30 \%$ \\
\hline 46 - 55 Years & 51 & $10.16 \%$ \\
\hline $56-65$ Years & 10 & $1.99 \%$ \\
\hline Total & 502 & $100.00 \%$ \\
\hline Education & Frequency & Percent \\
\hline High School & 39 & $7.77 \%$ \\
\hline College & 36 & $7.17 \%$ \\
\hline Bachelor & 288 & $57.37 \%$ \\
\hline Master & 118 & $23.51 \%$ \\
\hline Doctoral & 21 & $4.18 \%$ \\
\hline Total & 502 & $100.00 \%$ \\
\hline Travel Classes & Frequency & Percent \\
\hline Economy & 461 & $67.01 \%$ \\
\hline Business & 173 & $25.15 \%$ \\
\hline First & 54 & $7.85 \%$ \\
\hline Total & 688 & $100.00 \%$ \\
\hline
\end{tabular}

\subsection{SAUDIA Pre-Flight Operational Procedures}

The operational procedures (OP) dimension contained six questions classified as (level of satisfaction five-point Likert scale), plus two questions were a close-ended (Yes/No) questions. As shown in (Table 3) the overall passengers' perception of the operational procedures dimension six questions, illustrated that the passengers were Unsatisfied. 
Table 3. Overall Passengers' Perception (ASQUAL D6 - Operational Procedures)

\begin{tabular}{cccccc}
\hline \multicolumn{5}{c}{ Overall Passengers' Perception - 6 Questions } \\
ASQUAL D6 - Operational Procedures (level of satisfaction - five-point Likert scale) & \\
\hline \multicolumn{2}{c}{ Domain } & Mean & Std. Deviation & Mode & Variance \\
\hline Overall Operational Procedures & 2.58 & .812 & 3 & .659 \\
& Categorical answer & Frequency & Percent & Valid Percent & Cumulative Percent \\
& Strongly Unsatisfied & 34 & 6.8 & 6.8 & 6.8 \\
& Unsatisfied & 204 & 40.6 & 40.6 & 47.4 \\
Valid & 208 & 41.4 & 41.4 & 88.8 \\
& Neutral & 49 & 9.8 & 9.8 & 98.6 \\
& Satisfied & 7 & 1.4 & 1.4 & 100.0 \\
& Strongly Satisfied & 502 & 100.0 & 100.0 & \\
\hline
\end{tabular}

Also, (Table 4) illustrated the overall perception of the OP two issues reflecting that there are -at least- two operational services were not offered by SAUDIA. Consequently, that considered as a lack of quality of the provided service, which would indicate more dissatisfaction.

Table 4. Overall passengers' perception (ASQUAL D6 - operational procedures)

\begin{tabular}{|c|c|c|c|c|c|}
\hline \multicolumn{6}{|c|}{$\begin{array}{l}\text { Overall Passengers' Perception - } 2 \text { Questions } \\
\text { AL D6 - Operational Procedures (Close-ended - Yes/No) }\end{array}$} \\
\hline \multicolumn{2}{|c|}{ Domain } & Mean & Std. Deviation & Mode & Variance \\
\hline \multicolumn{2}{|c|}{ Overall Operational Procedures } & 1.11 & .315 & 1 & .099 \\
\hline \multicolumn{2}{|c|}{ Categorical answer } & Frequency & Percent & Valid Percent & Cumulative Percent \\
\hline & NO & 446 & 88.8 & 88.8 & 88.8 \\
\hline \multirow[t]{2}{*}{ Valid } & Yes & 56 & 11.2 & 11.2 & 100.0 \\
\hline & Total & 502 & 100 & 100 & \\
\hline
\end{tabular}

Furthermore, additional particulars of the conducted analysis on each response of the OP dimension are illustrated in (Table 5).

Table 5. Passengers' Perception toward SAUDIA (D6 - Operational Procedures)

\begin{tabular}{|c|c|c|c|c|}
\hline ASQUAL D6 - Operational Procedures & Mean & Std. Deviation & Mode & Variance \\
\hline Part1: How satisfied are you with the SQ offered by SAUDIA for the follows: & \multicolumn{4}{|c|}{5 Satisfaction Levels /Likert Scale } \\
\hline 16 Waiting Time (Counters Queue) & 2.25 & 1.134 & 1 & 1.286 \\
\hline 21 Frequent Announcements (Final Boarding \& Pre-flight) ) & 3.14 & 1.205 & 4 & 1.451 \\
\hline 22 On-Time (Flight Departure) & 2.52 & 1.257 & 1 & 1.580 \\
\hline 53 Waiting Time (Baggage Arrival) & 2.16 & 1.108 & 1 & 1.227 \\
\hline 54 Announcement (Guidance to Specific Baggage Carousel) & 2.54 & 1.176 & 3 & 1.383 \\
\hline 55 Safety (Delivered Baggage) & 2.47 & 1.205 & 1 & 1.451 \\
\hline Part2: Does SAUDIA do /offer the follows: & \multicolumn{4}{|c|}{ No / Yes / N.A } \\
\hline 23 Announcement (Replacement for Delayed Flight) & 1.27 & .446 & 1 & .199 \\
\hline 28 Preannouncement (Replacement for Canceled Flight / 7+ Days Prior) & 1.06 & .229 & 1 & .052 \\
\hline
\end{tabular}

\subsection{Chi-Square}

Chi-square test according to (Saunders, Lewis, \& Thornhill, 2009) Statistical test to determine the probability (likelihood) that two categorical data variables are associated. A common use is to discover whether there are statistically significant differences between the observed frequencies and the expected frequencies of two variables presented in a cross-tabulation.

A chi-square test of independence was performed to examine the relationship between Gender and each one of ASQUAL dimensions variables. The test results tabulated in (Table:6) reveals that:

For D6: Overall chi-square value of 11.024 with 4 degrees of freedom (df). The significance of .026 (Asymp. 
Sig.) meant that the probability of the values in below table occurring by chance alone was less than 0.027 . Therefore, we concluded that the relationship between gender and D6 (Operational Procedures) was extremely unlikely to be explained by chance factors alone where the statistic shows: $\left[\mathrm{X}^{2}=13.66, \mathrm{df}=4, \mathrm{p}<.05\right]$

Table 6. Chi-Square tests D6 - operational procedures * demographic profile - gender

\begin{tabular}{|c|c|c|c|c|c|c|}
\hline & Value & $\mathrm{df}$ & $\begin{array}{l}\text { Asymp. } \\
\text { (2-sided) }\end{array}$ & $\begin{array}{l}\text { Sig. Exact Sig. } \\
\text { (2-sided) }\end{array}$ & $\begin{array}{l}\text { Exact Sig. } \\
\text { (1-sided) }\end{array}$ & Point Probability \\
\hline Pearson Chi-Square & $11.024^{\mathrm{a}}$ & 4 & .026 & .026 & & \\
\hline Likelihood Ratio & 11.345 & 4 & .023 & .025 & & \\
\hline Fisher's Exact Test & 11.228 & & & .020 & & \\
\hline Linear-by-Linear Association & $10.599^{b}$ & 1 & .001 & .001 & .001 & .000 \\
\hline $\mathrm{N}$ of Valid Cases & 502 & & & & & \\
\hline
\end{tabular}

Note. a. 1 cells (10.0\%) have expected count less than 5. The minimum expected count is 1.60 .

Note. b. The standardized statistic is 3.256 .

\subsection{Spearman's RHO}

Spearman's rho employed in this study, (Table:7) illustrated the results for multiple variables, where it reveals the follows: For D6: There is a statistically significant positive relationship between D6 and Gender, and a statistically significant:

$$
[r=.138, p<.01]
$$

but a negative relationship between D6 and Age, and a statistically significant:

$$
[r=-.110, p<.05]
$$

also, a negative relationship between D6 and Education and a statistically significant

$$
[r=-.090, p<.05]
$$

Table 7. Spearman's rank correlation coefficient (Spearman's rho)

\begin{tabular}{llc}
\hline \multicolumn{2}{c}{ Spearman's rho } & $\begin{array}{c}\text { D6 - } \\
\text { Operational Procedures }\end{array}$ \\
& Correlation Coefficient & $.138^{* *}$ \\
Demographic Profile & .002 \\
Gender & Sig. (2-tailed) & 502 \\
& $\mathrm{~N}$ & $-.110^{*}$ \\
Demographic Profile & Correlation Coefficient & .014 \\
Age & Sig. (2-tailed) & 502 \\
& $\mathrm{~N}$ & .051 \\
Demographic Profile & Correlation Coefficient & .253 \\
Nationality & Sig. (2-tailed) & 502 \\
& $\mathrm{~N}$ & .036 \\
Demographic Profile & Correlation Coefficient & .424 \\
City & Sig. (2-tailed) & 502 \\
& $\mathrm{~N}$ & $-.090^{*}$ \\
Demographic Profile & Correlation Coefficient & .044 \\
Education & Sig. (2-tailed) & 502 \\
& $\mathrm{~N}$ & -.074 \\
Demographic Profile & Correlation Coefficient & .099 \\
Occupation & Sig. (2-tailed) & 502 \\
& $\mathrm{~N}$ & -.077 \\
Demographic Profile & Correlation Coefficient & .083 \\
Income & Sig. (2-tailed) & 502 \\
\hline & $\mathrm{N}$ & \\
\hline
\end{tabular}




\section{Conclusion and Discussion}

The Saudi Arabian Airlines (SAUDIA) that signed a contract to conduct studies for the privatization on Oct 2000 and still in restructured preparation phase does not reflect an auspicious level of quality service. To a large degree, the operational and organizational processes and procedures conducted by SAUDIA seemingly does not sate its passengers' appetite toward a service quality that touches their aspirations and expectations.

Obviously, SAUDIA is undergoing inflation status and administrative sagging that slows or even impedes any steps that would lead to the delivery of quality service to compete with their counterparts on customer satisfaction and enlarge its market shares toward outside its domestic market, which almost monopolized by SAUDIA.

SAUDIA may need to focus on enhancing several aspects such as; passengers' first impression, the speed of service (e.g., relating to queues), availability and accuracy of information. Also, dealing with complaints and other problems before occurring, by securing compensation procedures guidance, and work with the idea of being initiator rather than being just a reactor.

Moreover, SAUDIA needs to consider customer loyalty highly and promotes a positive image to attracts new passengers, where it would be a new wave of trust that could support to gains wide range of its passengers' confidence.

Thus, SAUDIA should possess well-understanding of the media influence, and utilize it considering the business ethics. There are several aspects require more professional treatment utilizing competitive advantage improve staff morale, to avoid the decline in the strength of the firm, and confront decreased sales, fewer customers, poor public image, a demoralized workforce, dissatisfied customers, lack of customer loyalty.

SAUDIA may need to pay more attention to legal consequences, such as litigation, compensation payments, court costs, negative press coverage. Also, financial implications, such as retraining staff, rebuilding brand, reputation, and new marketing processes.

\subsection{Recommendations and Policy Implications}

First: It makes sense that the recommendations begin by emphasizing the importance of looking closely at the shortcomings revealed by this study, and work on them urgently and specifically. Therefore, the first recommendation to the company is that it must exert its efforts to improve SAUDIA operational and organizational processes and procedures. Consequently, the study suggests the following (a) To utilizing successful cases to systematize efficiently and reduce passengers' waiting time at queue lines, whether at the front of its airport counters, offices, or baggage arrival area, (b) Launching media campaign to enhance every newly developed procedure, using the short films throughout social media to simplify the know-how of using the newly added feature. It would be very harmful to launch a service that almost no one aware of its existence, as long as - for instance - the tickets refund at SAUDIA offices is a very disappointing procedure while very few those using the E-refund service, (c) Handling last-minute passenger carefully is a crucial indicator for SAUDIA to assess frontlines representatives, (d)SAUDIA passengers believe that baggage safety is a weak point of their air carrier, it necessitates to reform and develop all baggage related systems.

Second: A perfect example can be suggested to utilize this study's findings: is to restructure the booking facility according to the passengers' preferences. Consequently, adding tens of touchscreens connected to SAUDIA reservation webpage would lead to (a) Reduces dissatisfaction of queues waiting time front of SAUDIA counters at the airports those serve flight reservations and tickets sales, (b) Reduces the operational cost, where lowering the representatives those serve in flight reservations and tickets sales. In contrast, adding a technological facility would lead to exchange high variable costs paid monthly, with very reasonable fixed costs paid at once. Where the study reviles that passengers' preference of SAUDIA Website 49\%, Mobile App 21\%, Reservation Call Center (RCC) $10 \%$, Offices \& Counters $9 \%$.

Third: SAUDIA should comply to GACA (General Authority of Civil Aviation) regulations and instructions, particularly the compensation system, and other international regulations addressed to air carriers worldwide.

Fourth: SAUDIA should highly consider the importance of its personal performance and conduct an extensive evaluation to explore the significant factors impacts their enthusiasm, not to mention the importance of SAUDI frontline representatives.

Fifth: SAUDIA may consider more participation in society contributions program to reform its image instated of pure commercial advertisement. It is important to address a serious question to SAUDIA leaders; that is: does SAUDIA has a real corporate social responsibility? Alternatively, is it just a CSR? 
Finally, as SAUDIA is the sole national air carrier for decades, it is expected to react as a leader in its market, it is carrying out the country image, where that urges SAUDIA to employ the new competition and provide better services and compete fairly to gain the passengers satisfaction as the ultimate goal.

\subsection{Further Studies}

This study urges researchers interested in inquiring into another part of SAUDIA service quality, may concentrate on ALFURSAN program members, where such VIP services would reveal deeper strength/weakness areas of SAUDI SQ.

Other studies may tend to compare SAUDIA SQ to its counterparts, or competitors, where newcomers to Saudi Arabia aviation markets would highly expect to be an influence on the market balance and reinforce another business formula.

Furthermore, it urges Service Quality field researcher to investigate the importance of exploring a method to weight unavailability of a service in satisfaction level, and answer such question:

- How to assesses unavailability of a service by a disaffection level comparing to the disaffection level toward a low quality of an existed service?

\section{References}

Abbott, L. (1955). Quality and Competition. New York: Columbia University Press (Reprinted Greenwood Press, Westport, Conn. 1973).

AMA, A. M. (1960). Marketing definitions: A glossary of marketing terms. Chicago: American Marketing Association.

AMA, A. M. (1995). Marketing definitions: A glossary of marketing terms (2nd ed.). Chicago: American Marketing Association.

Baker, D. (2013). Service Quality and Customer Satisfaction in the Airline Industry: A Comparison between Legacy Airlines and Low-Cost Airlines. American Journal of Tourism Research, 2(1), 67-77. https://doi.org/10.11634/216837861403317

Baruch, J. J., Quinn, J. B., \& Paquette, P. C.. (1987). Technology in services. Sci. Amer, 257(2), 50.

Bennett, B. M., Hoffman, D. D., \& Prakash, C. (1989). Observer mechanics: a formal theory of perception. San Diego, Calif: Academic Press.

Berelson, B., \& Steiner, G. A. (1964). Human behavior: An inventory of scientific findings. New York: Harcourt, Brace \& World.

Berry, L. L., Parasuraman, A., \& Zeithaml, V. A. (1988). SERVQUAL: A multiple-item scale for measuring consumer perceptions of service quality. Journal of Retailing, 64(1), 12-40.

Bishop, M. (2004). Essential Economics (1st ed.). Bloomberg Press, Economist Books.

Broh, R. A. (1982). Managing Quality for Higher Profits: A Guide for Business Executives and Quality Managers. New York: McGraw-Hill.

Buttle, F. (1996). SERVQUAL: review, critique, research agenda. European Journal of Marketing, 30(1), 8-32.

Crosby, P. B. (1979). Quality is free: The art of making quality certain. New York.

Deming, W. E. (1982). Quality, Productivity, and Competitive Position. Cambridge, MA: Massachusetts Institute of Technology.

Deming, W. E. (2000). Out of the Crisis. Cambridge, MA: Massachusetts Institute of Technology.

Deming, W. E. (2009). A System of Profound. The Economic Impact of Knowledge, 161.

Edwards, C. D. (1968). The meaning of quality. Quality Progress, 1(10), 36-39.

Farris, P. W., Bendle, N. T., Pfeifer, P. E., \& Reibstein, D. J. (2010). Marketing Metrics: The Definitive guide to measuring marketing performance. Pearson Education.

Feigenbaum, A. V. (1961). Total Quality Control: Engineering and Management: the Technical and Managerial Field for Improving Product Quality, Including Its Reliability, and for Reducing Operating Costs and Losses (2 ed.). New York: McGraw-Hill.

GACA. (2014). Statistical Year Book. Jeddah: GACA. Retrieved from https://www.gaca.gov.sa/en-us/Statistics/Documents/2014/AnnualBook2014e.pdf 
Garvin, D. A. (1984). What does "product quality" really mean? Sloan management review, 26(1), 25-43.

Garvin, D. A. (1988). Managing quality: The strategic and competitive edge. New York: Simon and Schuster Inc. GASTAT. (2010). The General Population and Housing Census. Riyadh: General Authority for statistics.

Gilmore, H. L. (1974). Product conformance cost. Quality Progress, 7(5), 16-19.

Gourdin, K. N. (1988). Bringing quality back to commercial air travel. Transportation Journal, 23-29.

Grove, S. K., Gray, J. R., \& Burns, N. (2014). Understanding Nursing Research: Building an Evidence-Based Practice. Missouri, United States: Elsevier Health Sciences.

Heuer, R. J. (1999). Psychology of Intelligence Analysis. Lulu. com. Retrieved from https://www.cia.gov/library/center-for-the-study-of-intelligence/csi-publications/books-and-monographs/ps ychology-of-intelligence-analysis/PsychofIntelNew.pdf

IATA. (2015). Economic and Social Benefits of Air Transport. ATAG. Oxford Economics. Retrieved from https://www.iata.org/pressroom/facts_figures/fact_sheets/Documents/fact-sheet-economic-and-social-benefi ts-of-air-transport.pdf

IBM SPSS, S. (2014). IBM SPSS Statistics 23 Brief Guide. Armonk, New York: IBM Corporation. Retrieved from $\mathrm{ftp} / / /$ public.dhe.ibm.com/software/analytics/spss/documentation/statistics/23.0/en/client/Manuals/IBM_SPS S_Statistics_Brief_Guide.pdf

ISO/IEC. (2008). Development of service standards - Recommendations for addressing consumer issues. Geneva: International Organization for Standardization.

ISO:9000. (2015). Quality management systems - Fundamentals and vocabulary. Geneva: International Organization for Standardization. Retrieved from https://www.iso.org/obp/ui/\#iso:std:iso:9000:ed-4:v1:en

Johnston, R., \& Clark, G. (2008). Service Operations Management: Improving Service Delivery. Financial Times, 533.

Juran, J. M. (1974). Quality Control Handbook (3d ed.). New York: McGraw-Hill.

Juran, J. M. (1981). Product quality: a prescription for the west. New York: AMACOM.

Juran, J. M., and Defeo, J. (2010). Juran's Quality Handbook. New York: McGraw Hill Professional.

Kent, U. (2016). Frequency distribution for categorical data. Retrieved from KENT STATE UNIVERSITY: http://libguides.library.kent.edu/SPSS/FrequenciesCategorical

Khatib, F. S. (1998). An Investigation of Airline Service Quality, Passenger Satisfaction and Loyalty: The Case of Royal Jordanian Airline. (Doctoral dissertation, Sheffield University), 428.

Kuehn, A., \& Day, R. (1962). Strategy of product quality. Harvard Business Review, 101.

Leffler, K. B. (1982). Ambiguous changes in product quality. American Economic Review, 72(5), 956-967.

Lewis, R. C., \& Booms, B. H. (1983). The marketing aspects of service quality. Emerging perspectives on services marketing, 65(4), 99-107.

Lovelock, C. H. (1983). Classifying services to gain strategic marketing insights. The Journal of Marketing, 47(3), 9-22. https://doi.org/10.2307/1251193

Mândru, L. I. (2011). Paradigms of Total Quality Management. Recent Researched in Manufacturing Engineering.

McLeod, S. (2014). Research Methods. Retrieved from Simply Psychology: http://www.simplypsychology.org/sampling.html

Millier, A. (2014). Patient-reported outcomes instruments in schizophrenia: a review of psychometric properties. Open Journal of Medical Psychology, 3(2), 141-156. https://doi.org/10.4236/ojmp.2014.32017

Parasuraman, A. (1985). A conceptual model of service quality and its implications for future research. The Journal of Marketing, 41-50.

Pirsig, R. M. (1974). Zen and the Art of Motorcycle Maintenance: An Inquiry Into Values. New York: Bantam Books.

Plenkiewicz, P. \&. (2010). The Executive Guide to Business Process Management. iUniverse. 
Saunders, M., Lewis, P., \& Thornhill, A. (2009). Research Methods for Business Students (5th ed.). Harlow, England: Pearson Education.

Scott, L. M. (1994). Images in advertising: The need for a theory of visual rhetoric. Journal of consumer research, 252-273.

Suarez, J. G. (1992). Three Experts on Quality Management: Philip B. Crosby, W. Edwards Deming, Joseph M. Juran. Arlington VA: DTIC Document.

Tuchman, B. W. (1980). The decline of quality. New York Times Magazine, 2, 38-41.

WTO. (2010). Measuring Trade in Services : A training module produced by WTO / OMC Update includes changes in the Manual on Statistics of International Trade in Services. Geneva: WTO. Retrieved from https://www.wto.org/english/res_e/statis_e/services_training_module_e.pdf

Wu, H. C., \& Cheng, C. C. (2013). A hierarchical model of service quality in the airline industry. Journal of Hospitality and Tourism Management, 20, 13-22.

Zeithaml, V. A., Berry, L. L., \& Parasuraman, A. (1996). The behavioral consequences of service quality. Journal of Marketing, 13-46. Retrieved from http://search.proquest.com/docview/227724472?accountid=142908

Al-Jasser, S. b. (2015). Saudia passenger traffic rises $10.49 \%$ to 27.88 million. (ArabNews, Interviewer) Jeddah, Saudi Arabia. Retrieved from http://www.arabnews.com/news/688651

Rabin, J. H. (1983). Accent is on quality in consumer goods and services this decade. Marketing News, $17(5), 12$.

Berry, L. L., Parasuraman, A., \& Zeithaml, V. A. (1994). Improving service quality in America: lessons learned. The Academy of Management Executive, 8(2), 32-45.

\section{Copyrights}

Copyright for this article is retained by the author(s), with first publication rights granted to the journal.

This is an open-access article distributed under the terms and conditions of the Creative Commons Attribution license (http://creativecommons.org/licenses/by/4.0/). 